\title{
Solar radiation use efficiency by soybean under field conditions in the Amazon region
}

\author{
Paulo Jorge de Oliveira Ponte de Souza(1), Aristides Ribeiro(2), Edson José Paulino da Rocha( ${ }^{(3)}$, \\ José Renato Bouça Farias ${ }^{(4)}$, Renata Silva Loureiro ${ }^{(3)}$, Carlos Capela Bispo ${ }^{(3)}$ and Leila Sampaio ${ }^{(1)}$
}

\begin{abstract}
(1)Universidade Federal Rural da Amazônia, Caixa Postal 917, CEP 66077-530 Belém, PA, Brazil. E-mail: paulo.jorge@ufra.edu.br, leila.sampaio@ufra.edu.br (2)Universidade Federal de Viçosa, Departamento de Engenharia Agrícola, CEP 36570-000 Viçosa, MG, Brazil. E-mail: ribeiro@ufv.br ${ }^{(3)}$ Universidade Federal do Pará, Departamento de Meteorologia, Caixa Postal 1611, CEP 66075-110 Belém, PA, Brazil. E-mail: eprocha@ufpa.br, renatasloureiro@hotmail.com, cjcapela@yahoo.com.br ${ }^{(4)}$ Embrapa Soja, Caixa Postal 231, CEP 86001-970 Londrina, PR, Brazil. E-mail: jrenato@cnpso.embrapa.br
\end{abstract}

\begin{abstract}
The objective of this work was to evaluate the efficiency of soybean (Glycine max) in intercepting and using solar radiation under natural field conditions, in the Amazon region, Brazil. The meteorological data and the values of soybean growth and leaf area were obtained from an agrometeorological experiment carried out in Paragominas, Pará state, during 2007 and 2008. The radiation use efficiency (RUE) was obtained from the ratio between the above-ground biomass production and the intercepted photosynthetically active radiation (PAR) accumulated to 99 and 95 days after sowing, in 2007 and 2008, respectively. Climatic conditions during the experiment were very distinct, with reduction in rainfall in 2007, which began during the soybean mid-cycle, due to the El Niño phenomenon. An important reduction in the leaf area index and biomass production was observed during 2007. Under natural field conditions in the Amazon region, the values of RUE were 1.46 and $1.99 \mathrm{~g} \mathrm{MJ}^{-1}$ PAR in the 2007 and 2008 experiments, respectively. The probable reason for the differences found between these years might be associated to the water restriction in 2007 coupled with the higher air temperature and vapor pressure deficit, and also to the increase in the fraction of diffuse radiation that reached the land surface in 2008.
\end{abstract}

Index terms: Glycine max, Amazon region, leaf area index, radiation interception.

\section{Eficiência do uso da radiação solar pela soja em condições de campo na região Amazônica}

\begin{abstract}
Resumo - O objetivo deste trabalho foi avaliar a eficiência da soja (Glycine max) em interceptar e usar a radiação solar em condições naturais de campo, na região Amazônica do Brasil. Os dados de crescimento e área foliar da soja e dados meteorológicos foram obtidos em um experimento agrometeorológico realizado em Paragominas, PA, em 2007 e 2008. A eficiência do uso da radiação (ERU) foi obtida pela razão entre a produção de massa de matéria seca da parte aérea e o acúmulo da radiação fotossinteticamente ativa interceptada (RFA), até os 99 e 95 dias após a semeadura, em 2007 e 2008, respectivamente. As condições climáticas durante o experimento foram muito distintas, com redução na precipitação em 2007, iniciada na metade do ciclo de cultivo de soja, em consequência do fenômeno El Niño. Observou-se uma importante redução no índice de área foliar e na produção de massa de matéria seca durante 2007. Em tais condições de campo na região Amazônica, os valores de EUR foram de 1,46 e 1,99 $\mathrm{g} \mathrm{MJ}^{-1}$ RFA, nos experimentos de 2007 e 2008, respectivamente. A provável razão para as diferenças encontradas entre os anos pode estar associada à redução de água em 2007, em conjunto com a elevada temperatura do ar e o deficit de pressão de vapor, e também ao aumento na fração de radiação difusa que atingiu a superfície do solo em 2008.
\end{abstract}

Termos para indexação: Glycine max, região Amazônica, índice de área foliar, interceptação da radiação.

\section{Introduction}

In recent years, the agricultural frontier in the Amazon has been advancing at an increasing rate, and the soybean crop has often been considered the main responsible for this (Dantas \& Fonteles, 2005), which is a troublesome fact because of the impacts it causes on the regional climate pattern (Fearnside, 2001; Costa et al., 2007). Soybean culture [Glycine max (L.) Merr.] began to be developed in the Amazon in 2000, but it only occupied an insignificant area (73,000 ha), when compared to the remainder of Brazil (Dantas \& 
Fonteles, 2005). In Pará state, the cultivated area was only 1,200 ha in 2000, but this region has been receiving financial support from the government since 1994 to increase grain production, particularly in Santarém and Paragominas. In 2006, the cultivated area in Pará state reached 90,000 ha, with a mean productivity of $3 \mathrm{Mg}^{-1}$ (Governo do Pará, 2009).

Although these changes in the Amazon land use may cause serious environmental impacts, such as the decrease in local precipitation, in comparison to the reduction caused by land for pasture (Costa et al., 2007), it is important to highlight that the expansion of soybean culture towards low latitudes has occurred as a strategy to supply the increasing population growth and the consequent demand for food and biofuel.

Climatic factors are decisive to the success or failure of the crops. Solar radiation is a fundamental factor to determine the plant growth. The radiation use efficiency is the relation between the solar energy captured by the crop and its biomass production rate (Monteith, 1994). Such relation is defined as the efficiency with which the captured radiation is used to produce new material (Black \& Ong, 2000), and it has been successfully used as a tool to simulate the growth of different cultures (Albrizio \& Steduto, 2005).

Although solar radiation is a fundamental resource for crop growth, there are many other factors that influence plant development (Demetriades-Shah et al., 1992). Water availability for the plants, for example, is one of the most important factors for their development. Under some optimal conditions of water availability, the radiation use efficiency (RUE) remains almost constant throughout most of the plant growth cycle, and shows no effects caused by local atmospheric conditions (Muchow et al., 1993). Some results have shown a dependence of RUE on the meteorological factors such as those found for soybean (Muchow et al., 1993), peanut (Collino et al., 2001) and maize (Andrade et al., 1993). Factors such as vapor pressure deficit, air temperature and water stress are the most common elements responsible for variation in RUE.

Most crop growth models rely on information on the interactions between culture and environment. Specifically in Amazonia, where soybean expansion has been occurring intensely, little is known about the response of soybean to local environmental conditions.
The objective of this work was to determine the radiation use efficiency of soybean in the Amazon region, under natural field conditions.

\section{Materials and Methods}

The experiment was carried out during 2007 and 2008, in Paragominas county, Pará state, Brazil. The experimental site was set up in a soybean crop area with a continuous extension of 200 ha $\left(02^{\circ} 59^{\prime} 08^{\prime \prime} \mathrm{S}\right.$ and $\left.47^{\circ} 19^{\prime} 57^{\prime \prime} \mathrm{W}\right)$, in a Xanthic Hapludox soil, with $71 \%$ clay content. The volumetric water content at field capacity is $0.43 \mathrm{~m}^{3} \mathrm{~m}^{-3}$ and $0.19 \mathrm{~m}^{3} \mathrm{~m}^{-3}$ at wilting point. The soil was tilled in the rainy season and, later, the whole area was mechanically sown with BRS Tracajá (intermediate maturity), which is the most recommended soybean cultivar for this region (El-Husny et al., 2003). The plant population was 200,000 plants $\mathrm{ha}^{-1}$ at $0.50-\mathrm{m}$ row spacing. Prior to sowing, seeds were prepared with an adequate rhizobium inoculant, fungicides and insecticides. Seeds were sown on February 23, 2007 and February 7, 2008 with 26-28 seeds $\mathrm{m}^{-2}$. The soil was fertilized with $\mathrm{N}, \mathrm{P}$ and $\mathrm{K}$ of 2-20-18 chemical fertilizer at $640 \mathrm{~kg} \mathrm{ha}^{-1}$ during sowing. The final harvest was carried out in June 21, 2007 and June 06, 2008.

A 3-meter-high instrumented micrometeorological tower was installed in the center of the experimental area. Meteorological sensors were connected to a CR10X datalogger (Campbell Scientific, Inc., Utah, USA) and to a AM416 multiplex (Campbell Scientific, Inc., Utha, USA). The incident solar and photosynthetically active radiation (PAR), transmitted PAR, relative humidity, air temperature and rainfall were continuously monitored. Data measurements were made every ten seconds, during 2007 and 2008, providing totals and averages every ten minutes. The data acquisition period used in this work ranges from February to June in 2007 and in 2008.

The incident PAR was measured by a quantum sensor (LI-190SA, Licor Biosciences, Lincoln, NE, USA) located on the top of the tower. The PAR transmitted to the ground was continuously measured by a line quantum sensor (LI-191SA, Licor Biosciences, Lincoln, NE, USA) installed at the soil surface diagonally across rows, similarly to several works (Lindquist et al., 2005). The sensor was moved weekly around the tower to ensure randomness and avoid bias in the intercepted radiation data. 
The estimation of the daily PAR intercepted by the soybean canopy was obtained by the difference between the daily total incident and the transmitted PAR. A correlation was done between the accumulated intercepted radiation and the rate of the above-ground biomass production in order to provide the RUE. The RUE was determined as the angular coefficient of the linear regression between the total above-ground dry matter and the cumulative intercepted PAR (Monteith, 1994). The period of the data used in the regression was up to 99 days after sowing (DAS) in 2007, and 95 DAS in 2008 , once the data near the maturity stage do not present any physiological importance in these analyses, contributing only to a variation at RUE (Black \& Ong, 2000).

The fraction of transpirable soil water (FTSW) was calculated as the ratio between the actual quantity of transpirable water and the total-potential transpirable soil water according to Sinclair (1986), in order to provide information about available water to the culture. The actual amount of daily transpirable water is reduced through soil evaporation and transpiration of the plant. The potential soil evaporation is calculated by Penman's method, and the actual soil evaporation is obtained using a correction according to the degree of radiation intercepted by the soil and the time since the last rain occurred (Sinclair, 1986). Crop transpiration is obtained by the Penmam-Monteith method applied to the canopy and the aerodynamic resistance (Allen et al., 1996). The value of FTSW ranges from 1 at field capacity to 0 when all of the water available for transpiration has been extracted. The mean diurnal vapor pressure deficit was calculated as the mean difference between the saturated and actual vapor pressure obtained from relative humidity and air temperature data between 6 and 18 local time in a 10-min interval.

The data for growth analyses were collected weekly, starting at ten DAS. The plants samples consisted of randomly chosen 1-meter rows with six replicates. All samples were kept in paper bags until they were processed in the laboratory. They were separated into leaves, stems, petioles, flowers and pods and were oven-dried at $70^{\circ} \mathrm{C}$. The phenological development was observed daily, according to Farias et al. (2007). The leaf area index (LAI) was estimated by the "disc method" according to the methodology described by Benincasa (2003). Thirty discs were collected in replicate, oven-dried and weighted. The LAI was estimated taking into account these measurements and the leaf dry weight. The averages of RUE were analyzed by the $t$ test at $5 \%$ of probability.

\section{Results and Discussion}

In 2007 precipitation was reduced, with a total monthly amount lower than the normal rain regime and lower than the amount observed in 2008 (Figure 1), which resulted in lower values of fraction of transpirable soil water in the first year (Figure 2). This reduction in rainfall might have been caused by a positive anomaly in the surface temperature of the Pacific Ocean, observed during October 2006 and April 2007, indicating the occurrence of El Niño (Brazil, 2009).

The 2008 experiment was carried out in a year that can be considered rainy, compared to the mean, which showed, in most months, an increase in total rain

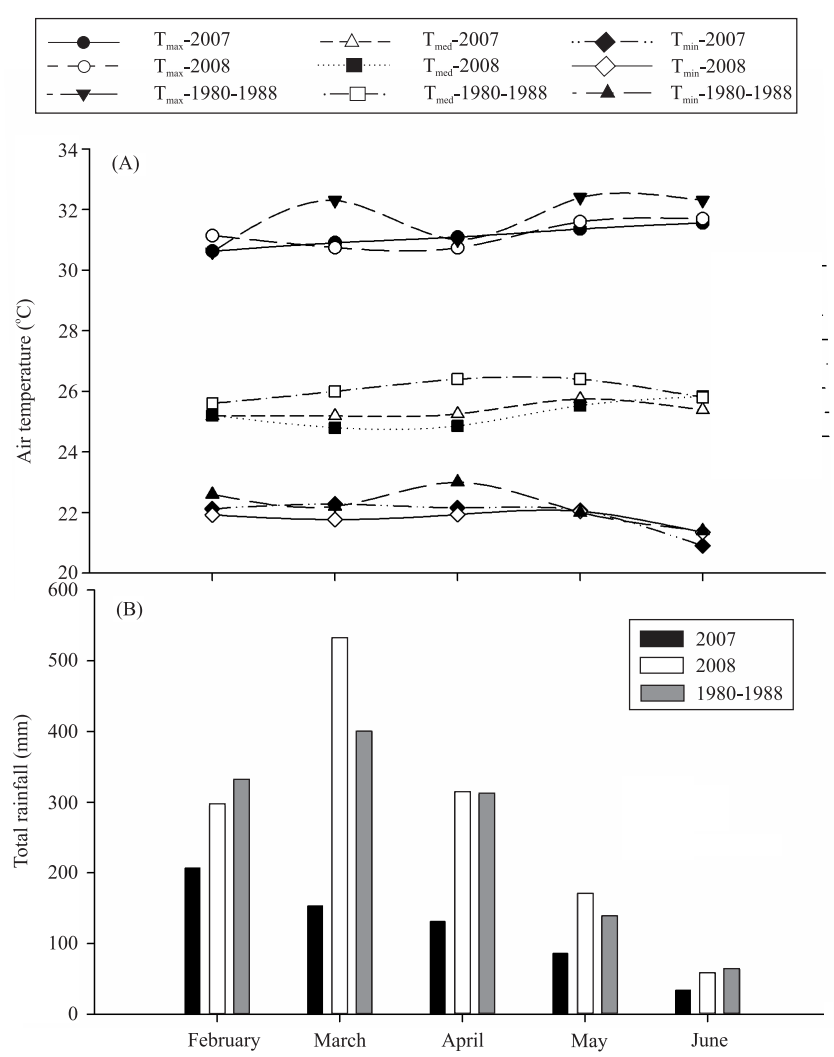

Figure 1. Air temperature regimes (A) and total rain fall (B) observed in the 2007 and 2008 experiments, and mean air temperature (A), and mean total rain fall (B) between 1980-1988. Source: Embrapa Amazônia Oriental (1988). 
especially at the beginning of the cycle, when seeds need a reasonable amount of soil humidity during sowing (Table 1).

In 2007, rainfall amount in April was $130 \mathrm{~mm}$, less than half of the mean value (Figure 1) which could have been responsible for the difference observed in biomass production that year. At the beginning of the seed growth stage, the total rain that year was $61.6 \mathrm{~mm}$, resulting in a daily mean of only $1.86 \mathrm{~mm}$, which is too low to supply the seed water requirement during this phase (Table 1). The total precipitation of the whole cycle was $1,253 \mathrm{~mm}$ in 2008 , and $410 \mathrm{~mm}$ in 2007 , which is close to the lower limit of the soybean cycle demand (Farias et al., 2007). The mean productivity observed during the experiment was $3.47 \mathrm{Mg} \mathrm{ha}^{-1}$ in 2007 and $3.70 \mathrm{Mg} \mathrm{ha}^{-1}$ in 2008.

The decrease observed in the FTSW in 2007 indicated the occurrence of moderate water deficit that started in early April and persisted until the end of the cycle. The FTSW was 0.75 , during the vegetative stage, and showed a marked reduction starting from the R5 phase (Figure 2). Despite these differences between the years, the critical FTSW (0.35) commonly established to cause

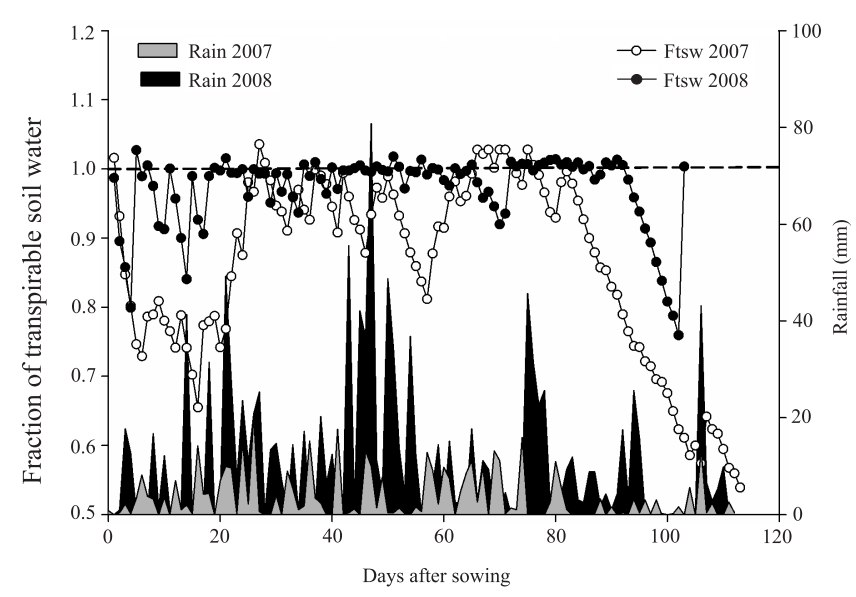

Figure 2. Fraction of transpirable soil water (FTSW) and rainfall in 2007 and 2008. down regulation on the RUE of some crops was never reached, although an early stomatal closure has been observed even at early stage of soil drying as a strategy to preserve soil water (Sinclair \& Muchow, 2001).

The air temperature was higher in 2007 than in 2008, but lower than normal, with a mean of $27^{\circ} \mathrm{C}$, and maximum always below $34^{\circ} \mathrm{C}$ (Figure 1). Even though the air temperature in 2007 always remained above that of 2008 (ca. $0.4^{\circ} \mathrm{C}$ ), the values observed during the experiment are consistent with the limits supported by the soybean culture (Farias et al., 2007).

The mean daily incident solar radiation was below $20 \mathrm{MJ} \mathrm{m}^{-2}$ during the whole cycle, with mean values of PAR around $8 \mathrm{MJ} \mathrm{m}^{-2}$, although the daily values of $12 \mathrm{MJ} \mathrm{m}^{-2}$ were observed in some days, but rarely reaching values below $6 \mathrm{MJ} \mathrm{m}^{-2}$ day $^{-1}$ (Table 1). Such conditions might be considered as not limiting to soybean growth in comparison to other regions of Brazil. In 2007, the irradiative regime was higher than that observed in 2008, as a result of lower cloudiness suggested by the low rainfall values that occurred in 2007.

The biomass production, as well as the leaf area index, was higher during 2008 (Figure 3). The meteorological conditions during both experiments were very distinct, due to drought during most of the 2007 development cycle. Before $30 \mathrm{DAS}$, the difference in biomass production and, consequently, in leaf area index (LAI), was modest. From 56 DAS, soybean started to show an abrupt reduction in biomass production, as a possible response to lower water availability to which the plants were exposed during fruiting (R3) and initial seed growth stages (R5) in 2007. Water deficit tends to be more critical to soybean yield when it occurs during the reproductive stage (Oya et al., 2004).

The maximum LAI observed during the 2007 experiment was only $4.1 \pm 0.28$ at 81 DAS, while in 2008 it was $6.49 \pm 0.13$ at 67 DAS. The maximum above-ground biomass production before senescence

Table 1. Total rainfall, daily maximum $\left(\mathrm{T}_{\max }\right)$, minimum $\left(\mathrm{T}_{\min }\right)$ and mean air temperatures $\left(\mathrm{T}_{\text {mean }}\right)$, daily mean global incident radiation $\left(\mathrm{S}_{\mathrm{in}}\right)$, and photosynthetically active radiation (PAR), in each stage of soybean culture, in 2007 and 2008.

\begin{tabular}{|c|c|c|c|c|c|c|c|c|c|c|c|c|c|c|}
\hline \multirow[t]{2}{*}{ Stage } & \multicolumn{2}{|c|}{ Duration (days) } & \multicolumn{2}{|c|}{ Rainfall (mm) } & \multicolumn{2}{|c|}{$\mathrm{T}_{\max }\left({ }^{\circ} \mathrm{C}\right)$} & \multicolumn{2}{|c|}{$\mathrm{T}_{\min }\left({ }^{\circ} \mathrm{C}\right)$} & \multicolumn{2}{|c|}{$\mathrm{T}_{\text {mean }}\left({ }^{\circ} \mathrm{C}\right)$} & \multicolumn{2}{|c|}{$\mathrm{S}_{\mathrm{in}}\left(\mathrm{MJ} \mathrm{m}^{-2}\right)$} & \multicolumn{2}{|c|}{$\operatorname{PAR}\left(\mathrm{MJ} \mathrm{m}^{-2}\right)$} \\
\hline & 2007 & 2008 & 2007 & 2008 & 2007 & 2008 & 2007 & 2008 & 2007 & 2008 & 2007 & 2008 & 2007 & 2008 \\
\hline Vegetative & 44 & 40 & 184.2 & 401.8 & 31.2 & 30.9 & 22.1 & 21.8 & 25.3 & 25.0 & 20.0 & 18.9 & 9.5 & 8.4 \\
\hline Flowering & 11 & 16 & 36.0 & 397.0 & 31.1 & 30.4 & 22.4 & 21.9 & 25.4 & 24.6 & 18.5 & 17.2 & 8.9 & 7.2 \\
\hline Fruiting & 17 & 10 & 105.2 & 72.2 & 30.8 & 30.6 & 22.1 & 21.5 & 25.2 & 24.8 & 18.7 & 18.5 & 9.0 & 7.5 \\
\hline Seed growth & 33 & 46 & 61.6 & 289.5 & 31.4 & 31.1 & 21.8 & 22.2 & 25.7 & 25.2 & 19.9 & 18.1 & 9.6 & 7.2 \\
\hline Maturation & 14 & 19 & 23.4 & 92.5 & 31.7 & 31.8 & 20.9 & 21.8 & 25.5 & 25.6 & 19.0 & 18.9 & 9.2 & 7.2 \\
\hline
\end{tabular}


was $805 \pm 27.4$ and $995 \pm 24.5 \mathrm{~g} \mathrm{~m}^{-2}$ in 2007 and 2008 , respectively. Some important reductions in the soybean LAI, due to the water deficits, were also observed by Oya et al. (2004).

During severe drought conditions, a considerable reduction occurs in the stomatal conductance, leading to an interruption in $\mathrm{CO}_{2}$ assimilation. Under such conditions, the water reserves of the plants themselves may be consumed, which can lead to the death of the plants (Sinclair, 2000). The reduction in LAI observed in 2007 was a strategy to reduce the water loss by soybean and to maintain the soil water uptake at satisfactory levels.

A strong relation is observed between the above-ground dry biomass production and cumulated intercepted radiation in both experiments (Figure 4). Soybean stopped showing a linear correlation at 99 DAS in 2007 and after 95 DAS in 2008, shortly before the physiological maturity (R7), when photosynthate translocation replaces radiation interception as the main factor for biomass production, (Black \& Ong, 2000).

The RUE of soybean in 2007 was ca. $1.46 \mathrm{~g} \mathrm{MJ}^{-1} \mathrm{PAR}$, considering the data to 99 DAS, when a nonlinearity near maturity can be observed. In the 2008 experiment, the value obtained was $1.99 \mathrm{~g} \mathrm{MJ}^{-1}$ PAR. The difference observed between both experiments clearly shows the effect of weather on the radiation use efficiency due

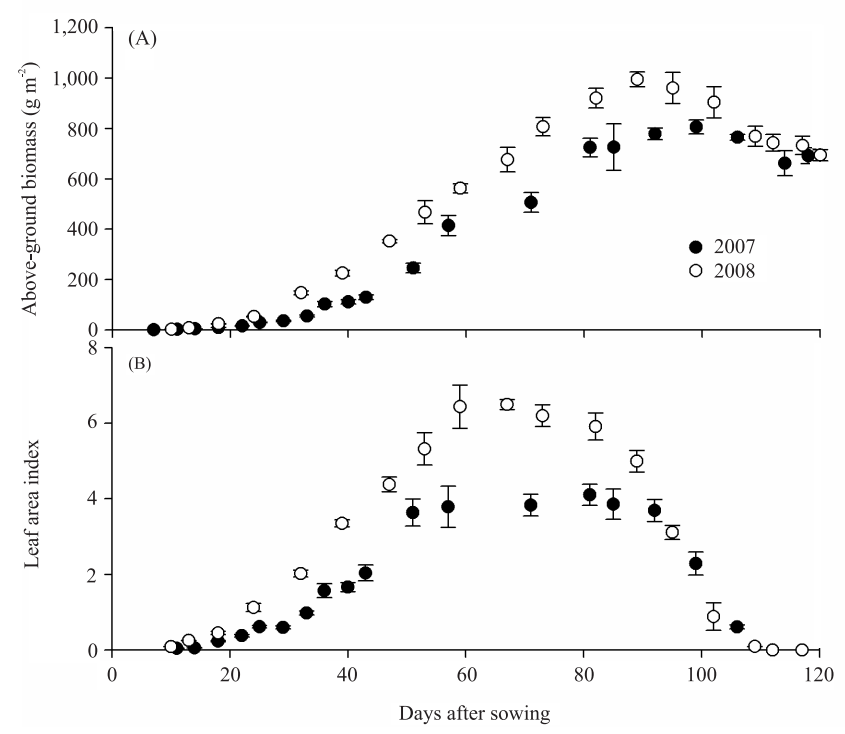

Figure 3. Soybean above-ground dry biomass production (A) and leaf area index (B) in 2007 and 2008. to the direct relation between biomass accumulation and its $\mathrm{CO}_{2}$ assimilation rate (Sinclair \& Horie, 1989), as reported by Confalone \& Dujmovich (1999) and Collino et al. (2001).

The RUE value found for the cultivar Tracajá, in 2008, was slightly higher than those found by Confalone \& Dujmovich (1999) in Argentina, were values ranged from $1.37 \mathrm{~g} \mathrm{MJ}^{-1}$ PAR, under irrigated conditions, to $1.92 \mathrm{~g} \mathrm{MJ}^{-1}$ PAR under natural field conditions with no water stress. Schöffel \& Volpe (2001) found a mean value for RUE around $1.23 \mathrm{~g} \mathrm{MJ}^{-1} \mathrm{PAR}$, for different cultivars in the Southeast of Brazil.

Other results reported in the literature present values for soybean RUE under natural field conditions, without water limitations, ranging from 2.28, before flowering to $2.53 \mathrm{~g} \mathrm{MJ}^{-1}$ PAR after flowering (Santos et al., 2003). Schöffel \& Volpe (2001) found mean values of $1.02 \mathrm{~g} \mathrm{MJ}^{-1}$ PAR in the vegetative subperiod, and $1.40 \mathrm{~g} \mathrm{MJ}^{-1}$ PAR in the reproductive subperiod under irrigated conditions, for several cultivars. The results from Confalone et al. (1998) showed a variation in RUE between $1.73 \mathrm{~g} \mathrm{MJ}^{-1} \mathrm{PAR}$, at the vegetative stage, and $1.86 \mathrm{~g} \mathrm{MJ}^{-1}$ PAR at flowering.

The time scale used to calculate RUE is extremely important, and it is one of the causes of the variations found in the literature (Black \& Ong, 2000). Although RUE is considered conservative for a unique culture under optimal water conditions (Muchow et al., 1993; Monteith, 1994), some works have presented small

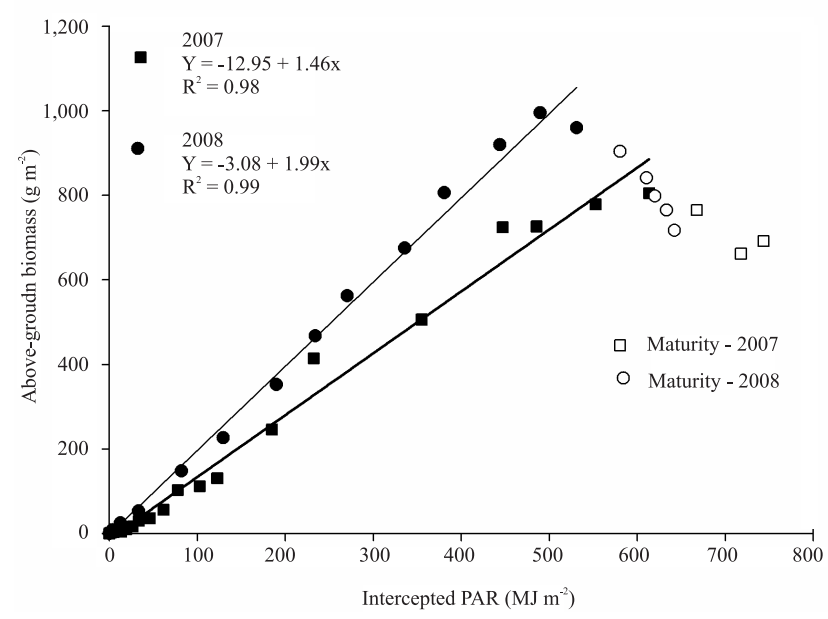

Figure 4. Relation between the rate of aerial or above ground dry biomass production of soybean and the accumulated intercepted radiation. 
variations in RUE, even when it was calculated for specific development stages (Arkebauer et al., 1994).

Soybean had different radiation convertion efficiency in both years before flowering, with angular coefficients of 1.14 and $1.75 \mathrm{~g} \mathrm{MJ}^{-1}$ PAR in 2007 and 2008, respectively (Table 2). Similarly, during the reproductive stage, soybean showed different values between years, as a consequence of the reduction in water availability in 2007. Despite these inter-annual differences, the RUE between stages in a single year was not significantly different according to the homogeneity test for different regressions ( $t$ test, $\mathrm{p}<0.05$ ).

The increase in the RUE found during the reproductive phase of soybean in 2008 is in accordance with most results found for soybean (Confalone \& Dujmovich, 1999; Schöffel \& Volpe, 2001; Santos et al., 2003). This increase is due to the increase in biomass accumulation and is significant only from the V5 phase on, remaining high until the beginning of the grain filling phase, when the assimilated translocation to the grains begins (Farias et al., 2007).

Although biomass production in the 2008 experiment was significantly higher than in 2007 during the vegetative phase (Table 2), the amount of radiation intercepted by soybean was not significantly different between both years, even though the biomass production in 2007 was only $57 \%$ of that in 2008 . Due to the water reduction in the reproductive phase in 2007 , the biomass production amount was ca. $80 \%$ of the 2008 value; however, there was an increase of $13 \%$ in the PAR radiation interception in the 2007 experiment compared to 2008.

There are two possible causes for this. First, since 2007 was drier (Figure 1), there was significantly lower cloud cover throughout the cycle than in 2008, with an increase in the amount of the incident PAR radiation during the experiment, with mean values during the reproductive phase ca. 9.2 and $7.3 \mathrm{MJ} \mathrm{m}^{-2}$ per day in 2007 and 2008, respectively.

Table 2. Dry biomass produced and intercepted radiation $\left(\mathrm{PAR}_{\mathrm{int}}\right)$, at the end of each stage, and the radiation-use efficiency (RUE) for each soybean stage, in 2007 and $2008^{(1)}$.

\begin{tabular}{|c|c|c|c|c|c|c|}
\hline \multirow[t]{2}{*}{ Stage } & \multicolumn{2}{|c|}{$\begin{array}{l}\text { Above ground dry } \\
\text { biomass }\left(\mathrm{g} \mathrm{m}^{-2}\right)\end{array}$} & \multicolumn{2}{|c|}{$\begin{array}{c}\text { PAR }_{\text {int }} \\
\left(\mathrm{MJ} \mathrm{m}^{-2} \text { day }^{-1}\right)\end{array}$} & \multicolumn{2}{|c|}{$\begin{array}{c}\text { RUE } \\
\left(\mathrm{g} \mathrm{MJ}^{-1} \text { PAR }\right)\end{array}$} \\
\hline & 2007 & 2008 & 2007 & 2008 & 2007 & 2008 \\
\hline Vegetative & $130.1 \mathrm{a}$ & $226.4 b$ & 122.6 & 129.3 & $1.14 \mathrm{a}$ & $1.75 b$ \\
\hline Reproductive & $805.4 \mathrm{c}$ & $960.2 \mathrm{c}$ & 613.4 & 531.1 & $1.29 \mathrm{a}$ & $1.91 \mathrm{~b}$ \\
\hline
\end{tabular}

The second reason is that, even with the reduction observed in the LAI between the experiments, the extinction coefficient found was 0.717 in 2007 and 0.715 in 2008. Although the maximum LAI obtained in 2008 was 6.5 , the critical value of LAI to intercept $95 \%$ of the radiation was ca. 4. In 2007, the maximum value obtained was of 4.1 , but the critical LAI to intercept $95 \%$ was around 3.8 , close to the value for 2008 . So, more available radiation and similar foliar area duration allowed a greater PAR radiation interception during the reproductive phase of 2007.

The differences in soybean RUE, between the 2007 and 2008 experiments, were probably influenced by differences in the meteorological conditions observed. The diurnal vapor pressure deficit (VPD) was not very different in the two experiments, despite the difference in water availability, which had means of $0.79 \mathrm{kPa}$, for the entire cycle in 2007 , and of $0.65 \mathrm{kPa}$ in 2008 . The difference between them was $0.14 \mathrm{kPa}$, which is too low to significantly affect the RUE, in comparison to the range observed in other works (Kiniry, 1999). The difference between those years was $0.086 \mathrm{kPa}$, during the reproductive stage, and it was $0.003 \mathrm{kPa}$ during the vegetative stage.

The difference in air temperature was only $0.59^{\circ} \mathrm{C}$ for the entire cycle $\left(25.65^{\circ} \mathrm{C}\right.$ in 2007 , and $25.06^{\circ} \mathrm{C}$ in 2008), it was $0.24^{\circ} \mathrm{C}$ during the vegetative stage and $0.83^{\circ} \mathrm{C}$ during the reproductive stage. Despite the higher difference at the reproductive stage, the variations observed in air temperature in Amazonia are not considered sufficient to lead to the differences observed in the radiation use efficiency by itself, when compared to the amplitudes in air temperature found by Andrade et al. (1993) (15.9-20.9 $\left.{ }^{\circ} \mathrm{C}\right)$.

Sinclair et al. (1992) found a great dependence of the RUE by soybean on the increase in diffuse radiation. With the increase in the fraction of diffuse radiation, there is an increase in biomass accumulation, due to the relative contribution of the shaded leaves, since they are much more photosynthetically efficient than those exposed to direct sun light, which contributes to the increase in radiation use efficiency.

Similar results were found by Alton et al. (2007), who attributed an increase of 6 to $33 \%$ in the RUE to the increase of the diffuse component in incident solar radiation. Rochette et al. (1996) observed a decrease of $30 \%$ in the RUE of maize, when atmospheric conditions changed from completely cloudy to a clear 
sky. According to Anderson et al. (2000), if 50\% of the beam radiation is adopted as a reference, instantaneous values of RUE in soybean may be $40 \%$ higher under diffuse light and $40 \%$ lower for a clear sky.

One of the specific characteristics of the Amazon region is that, during the period of the soybean cycle, from February to June (rainy season), the degree of cloudiness is relatively high during the whole day. It makes most of the incident radiation that reaches the soil surface as diffuse radiation, which could also contribute to the difference found between years. However, the absence of measured data and available information to corroborate this statement does not guarantee that this meteorological variable was the main cause of the difference found.

Drought caused reduction in dry matter production and leaf area in 2007, which represents a drought tolerance mechanism as a water conservation strategy by the crop. In such drought conditions, coupled with higher air temperature and VPD, the imminent closure of stomata induced lower $\mathrm{CO}_{2}$ fixation and, consequently, lower efficiency in the use of the intercepted radiation in 2007. Similar reduction in the soybean RUE under water stress was found by Confalone \& Dujmovich (1999) and Muchow et al. (1993).

Inamullah \& Isoda (2005) found that the reduction in the soybean $\mathrm{CO}_{2}$ assimilation rate under drought stress is related to the direct photodamaging effect of water scarcity and higher leaf temperature. This reduction is an adaptive characteristic of soybean to provide photoprotection of the photosystem, through the down-regulation of the photosystem activity (PSII) and by increasing thermal dissipation of excess absorbed light energy as heat (Inamullah \& Isoda, 2005).

\section{Conclusion}

The solar radiation use efficiency of soybean in the Amazon region is sensitive to weather conditions, and its value in a dry year is small as a consequence of coupled effect of the higher air temperature, vapor pressure deficit and the water deficit.

\section{Acknowledgements}

To Conselho Nacional de Desenvolvimento Cientifico e Tecnológico, for financial support; to Coordenação de Aperfeiçoamento de Pessoal de Nível
Superior, for postgraduate scholarship; to Dr. Celso Von Randow, for review of the language.

\section{References}

ALBRIZIO, R.; STEDUTO, P. Resource use efficiency of field-grown sunflower, sorghum, wheat and chickpea. I. Radiation use efficiency. Agricultural and Forest Meteorology, v.130, p.254-268, 2005.

ALlEN, R.G.; PEREIRA, L.S.; RAES, D.; SMITH, M. Crop evapotranspiration: guidelines for computing crop water requirements. Rome: FAO, 1996. 300p. (FAO. Irrigation and Drainage Paper, 56).

ALTON, P.B.; NORTH, P.R.; LOS, S.O. The impact of diffuse sunlight on canopy light-use efficiency, gross photosynthetic product and net ecosystem exchange in three forest biomes. Global Change Biology, v.13, p.776-787, 2007.

ANDERSON, M.C.; NORMAN, J.M.; MEYERS, T.P.; DIAK, G.R. An analytical model for estimating canopy transpiration and carbon assimilation fluxes based on canopy light-use efficiency. Agricultural and Forest Meteorology, v.101, p.265-289, 2000.

ANDRADE, F.H.; UHART, S.A.; CIRILO, A. Temperature affects radiation use efficiency in maize. Field Crops Research, v.32, p.17-25, 1993.

ARKEBAUER, T.J.; WEISS, A.; SINCLAIR, T.R.; BLUM, A. In defense of radiation use efficiency: a response to Demetriades-Shah et al. (1992). Agricultural and Forest Meteorology, v.68, p.221-227, 1994.

BENINCASA, M.M.P. Análise de crescimento de plantas: noções básicas. Jaboticabal: Funep, 2003. 41p.

BLACK, C.; ONG, C. Utilisation of light and water in tropical agriculture. Agricultural and Forest Meteorology, v.104, p.25-47, 2000.

BRASIL. Ministério da Ciência e Tecnologia. Centro de Previsão de Tempo e Estudos Climáticos. El Niño e La Niña. Available at: $<$ http://enos.cptec.inpe.br/>. Accessed on: 19 Oct. 2009.

COLLINO, D.J.; DARDANELLI, J.L.; SERENO, R.; RACCA, R.W. Physiological responses of Argentine peanut varieties to water stress. Light interception, radiation use efficiency and partitioning of assimilates. Field Crops Research, v.70, p.177-184, 2001.

CONFALONE, A.E.; COSTA, L.C.; PEREIRA, C.R. Crescimento e captura de luz em soja sob estresse hídrico. Revista Brasileira de Agrometeorologia, v.6, p.165-169, 1998.

CONFALONE, A.E.; DUJMOVICH, M.N. Influência do "deficit" hídrico sobre a eficiência da radiação solar em soja. Revista Brasileira de Agrociência, v.5, p.195-198, 1999.

COSTA, M.H.; YANAGY, S.N.M.; SOUZA, P.J.O.P.; RIBEIRO, A.; ROCHA, E.J.P. Climate change in Amazonia caused by soybean cropland expansion, as compared to caused by pastureland expansion. Geophysical Research Letter, v.34, 2007. Doi:10.1029/2007GL029271. 
DANTAS, T.M.; FONTELES, L.V. Avanço da fronteira agrícola na Amazônia. 2005. Available at: <http://www.oktiva.net/sispub/ anexo/9168>. Acessed on: 15 Jan. 2006.

DEMETRIADES-SHAH, T.H.; FUCHS, M.; KANEMASU, E.T.; FLITCROFT, I. A note of caution concerning the relationship between cumulated intercepted solar radiation and crop growth. Agricultural and Forest Meteorology, v.58, p.193-207, 1992.

EL-HUSNY, J.C.; ANDRADE, E.B. de; ALMEIDA, L.A. de; KLEPER, D.; MEYER, M.C. BRS Tracajá: cultivar de soja para a região sul do Pará. Belém: Embrapa Amazônia Oriental, 2003. 5p. (Embrapa Amazônia Oriental. Comunicado técnico, 83).

FARIAS, J.R.B.; NEPOMUCENO, A.L.; NEUMAIER, N. Ecofisiologia da soja. Londrina: Embrapa Soja, 2007. 9p. (Embrapa Soja. Circular técnica, 48).

FEARNSIDE, P.M. Soybean cultivation as a threat to the environment in Brazil. Environmental Conservation, v.28, p.23-28, 2001.

GOVERNO DO PARÁ. Secretaria de Agricultura. Evolução da produção no Estado do Pará por município de 1994 a 2008. 2009. Available at: <www.sagri.pa.gov.br>. Accessed on: 12 May 2009.

INAMULLAH; ISODA, A. Adaptive responses of soybean and cotton to water stress. II. Changes in $\mathrm{CO} 2$ assimilation rate, chlorophyll fluorescence and photochemical reflectance index in relation to leaf temperature. Plant Production Science, v.8, p.131-138, 2005.

KINIRY, J.R. Response to questions raised by Sinclair and Muchow. Field Crops Research, v.62, p.245-247, 1999.

LINDQUIST, J.L.; ARKEBAUER, T.J.; WALTERS, D.T.; CASSMAN, K.G.; DOBERMANN, A. Maize radiation use efficiency under optimal growth conditions. Agronomy Journal, v.97, p.72-78, 2005.

MONTEITH, J.L. Validity of the correlation between intercepted radiation and biomass. Agricultural and Forest Meteorology, v.68, p.213-220, 1994.
MUCHOW, R.C.; ROBERTSON, M.J.; PENGELLY, B.C. Radiation-use efficiency of soybean, mugbean and cowpea under different environmental conditions. Field Crops Research, v.32, p.1-16, 1993.

OYA, T.; NEPOMUCENO, A.L.; NEUMAIER, N.; FARIAS, J.R.B.; TOBITA, S.; ITO, O. Drought tolerance characteristics of Brazilian soybean cultivars - evaluation and characterization of drought tolerance of various Brazilian soybean cultivars in the field. Plant Production Science, v.7, p.129-137, 2004.

ROCHETTE, P.; DESJARDINS, R.L.; PATTEY, E.; LESSARD, R. Instantaneous measurement of radiation and water use efficiencies of a maize crop. Agronomy Journal, v.88, p.627-635, 1996.

SANTOS, J.B. dos; PROCÓPIO, S. de O.; SILVA, A.A. da; COSTA, L.C. Captação e aproveitamento da radiação solar pelas culturas da soja e do feijão e por plantas daninhas. Bragantia, v.62, p.147-153, 2003.

SCHÖFFEL, E.R.; VOLPE, C.A. Eficiência de conversão da radiação fotossinteticamente ativa interceptada pela soja para a produção de fitomassa. Revista Brasileira de Agrometeorologia, v.9, p.241-249, 2001.

SINCLAIR, T.R. Model analysis of plant traits leading to prolonged crop survival during severe drought. Field Crops Research, v.68, p.211-217, 2000.

SINCLAIR, T.R. Water and nitrogen limitations in soybean grain production. I. Model development. Field Crops Research, v.15, p.125-141, 1986.

SINCLAIR, T.R.; HORIE, T. Leaf nitrogen, photosynthesis, and crop radiation use efficiency: a review. Crop Science, v.29, p.90-98, 1989.

SINCLAIR, T.R.; MUCHOW, R.C. System analysis of plant traits to increase grain yield on limited water supply. Agronomy Journal, v.93, p.263-270, 2001.

SINCLAIR, T.R.; SHIRAIWA, T.; HAMMER, G.L. Variation in crop radiation-use efficiency with increased diffuse radiation. Crop Science, v.32, p.1281-1284, 1992.

Received on April 16, 2009 and accepted on September 16, 2009 